\title{
Die voorsienigheidsleer vanuit die gereformeerde belydenisskrifte teenoor Adrio König se voorsienigheidsleer - 'n Dogma-historiese beoordeling
}

\author{
Authors: \\ Morné Diedericks ${ }^{1}$ \\ Carel F.C. Coetzee ${ }^{1}$ \\ Affiliations: \\ ${ }^{1}$ Faculty of Theology, North- \\ West University, South Africa \\ Correspondence to: \\ Carel Coetzee \\ Email: \\ callie.coetzee@nwu.ac.za \\ Postal address: \\ PO Box 20655, Noordbrug \\ 2522, South Africa \\ Dates: \\ Received: 16 Apr. 2013 \\ Accepted: 04 Sept. 2013 \\ Published: 01 Nov. 2013 \\ How to cite this article: \\ Diedericks, M. \& \\ Coetzee, C.F.C., 2013, \\ 'Die voorsienigheidsleer \\ vanuit die gereformeerde \\ belydenisskrifte \\ teenoor Adrio König \\ se voorsienigheidsleer \\ - 'n Dogma-historiese \\ beoordeling', In die Skriflig/ \\ In Luce Verbi 47(1), Art. \\ \#720, 9 pages. http://dx.doi. \\ org/10.4102/ids.v47i1.720
}

\section{Copyright:}

C 2013. The Authors.

Licensee: AOSIS

OpenJournals. This work

is licensed under the

Creative Commons

Attribution License.
Read online:
König is ' $n$ aktuele en invloedryke teoloog en sy standpunte kan nie geïgnoreer word nie (Strauss 2004:123). König (2002:13) beskou homself as 'n gereformeerde teoloog alhoewel sy voorsienigheidsleer van die klassieke gereformeerde siening verskil. In sommige gevalle word König se teologie as reformatories gesien (bv. sy leer oor die regverdigmaking) en in ander gevalle weer nie, byvoorbeeld die leer oor die voorsienigheid (Strauss 2004:139). Volgens König (2002:33) is die klassieke gereformeerde verstaan van die voorsienigheid nie werklik vertroostend nie. Die klassieke gereformeerde siening van die voorsienigheid maak volgens König van God 'n bose God wat die kwaad beskik en dan net toekyk as die kwaad gebeur. König (2002:237) se oplossing vir die probleem van die klassieke gereformeerde siening is dat God nie ten volle in beheer is nie, maar dat Hy eendag eers in beheer sal kom. Hierdie siening van König is in stryd met die gereformeerde belydenis waarin bely word dat God deur sy voorsienige hand alle dinge onderhou en regeer. Die gevolgtrekking is dat König se voorsienigheidsleer in die lig van die gereformeerde belydenis nie vertroostend is of kan wees nie en net meer verwarring en wanhoop veroorsaak.

The teachings on providence from the reformed confessions seen against Adrio König's teachings on providence - a Dogma-historical evaluation. König is a contemporary and influential theologian and his views can not be ignored (Strauss 2004:123). König (2002:13) regards himself as a reformed theologian, but his doctrine on providence differs from the classic reformed view. In some cases, König's theology is viewed as reformed (eg. his doctrine on justification) but not in all cases, as is the case with the doctrine on providence (Strauss 2004:139). According to König (2002:33) the classic reformed understanding of providence is not comforting. Also, according to König, the classic reformed view of providence indicates God as an evil God who ordains evil, and then sits back and watches as it unfolds. König's (2002:237) solution for the problem of the classic reformed view is that God is not fully in control, but that He only will be in control one day. This view of König is in conflict with the reformed confession which confesses that God through his providential hand maintains and governs all things. The conclusion is that König's doctrine of providence is not comforting in the light of the reformed confession, and that it only causes more confusion and despair.

\section{Inleiding}

König staan bekend as 'n gereformeerde teoloog en sy leerstellings is ook in ooreenstemming met die gereformeerde belydenis oor sake soos die regverdigmaking. König se leer oor die voorsienigheid van God is egter in stryd met die gereformeerde belydenis oor die voorsienigheid van God (Strauss 2004:139). König (2002:33) meen dat die klassieke gereformeerde verstaan van die voorsienigheid nie werklik vertroostend is nie, maar dat dit van God 'n bose God maak wat die kwaad beskik en dan net toekyk wanneer dit gebeur. Volgens König (2002:237) is God oënskynlik nie ten volle in beheer nie, maar nog besig om in beheer te kom. Dit staan teenoor die gereformeerde belydenis waarin bely word dat God deur sy voorsienige hand alle dinge onderhou en regeer. König (2002) se boek, God, waarom lyk die wêreld só?, het baie reaksie van akademici ontlok. Die debatte bied goeie materiaal oor König se voorsienigheidsleer, maar onthul nie werklik die grondtrekke van König se voorsienigheidsleer self nie.

Naude (2002) huldig 'n positiewe standpunt ten opsigte van König se boek, God, waarom lyk die wêreld so?, en sluit sy koerantartikel af met dié woorde:

Uit 'n konfessionele hoek sou dit nou interessant wees om te sien wat König met die Nederlandse Geloofsbelydenis en veral die Dordtse Leerreëls se voorsienigheid gaan maak. Hy skuld ons nog 'n eksegese hiervan. (bl. 7) 
König (2002:235) sluit die laaste deel van sy boek af met 'n tipe kategismus. Dit word ook in 'n vraag-en-antwoordstyl gestel. Naude se vraag uit König se boek oor die konfessionele aard van sy voorsienigheidsleer is daarom heel gepas, omdat König self tot 'n persoonlike belydenis (professio) oor die voorsienigheid kom.

Die belydenis oor die voorsienigheid van God vanuit die gereformeerde belydenisskrifte en wat in hierdie artikel bespreek word, het onder geweldige druk gekom gedurende die laaste aantal jare. Dit is ook deur verskeie teoloë in dieselfde reformatoriese tradisie verwerp (Potgieter 1996:196). Oor die algemeen word die gereformeerde belydenisskrifte binne die reformatoriese tradisie gesien as 'n naspreek van die Skrif. König bely ook werklik die sola Scriptura en dat die Skrif die weg is wat gevolg moet word om die leer oor die voorsienigheid van God te verstaan. Die voorsienigheidsleer van König moet dus nie beskou word as vreemd en 'n uitskieter binne die reformatoriese tradisie nie. Dit moet in die konteks gesien word van ander teoloë soos byvoorbeeld Van de Beek (1984) en Wood (1992), omdat albei ook twyfel of die gereformeerde belydenisskrifte se leer oor die voorsienigheid van God werklik gereformeerd is.

\section{Die voorsienigheidsleer vanuit die gereformeerde belydenisskrifte Die voorsienigheid van God volgens die
ekumeniese belydenisskrifte}

In hierdie gedeelte word na die voorsienigheidsleer in die drie ekumeniese belydenisskrifte in die geheel gekyk. Vir 'n deeglike begrip van die voorsienigheidsleer word die volgende temas bespreek om die gereformeerde voorsienigheidsleer te belig: God as persoonlike God; God, ons Vader deur Christus; God as die drie-enige God; God as die skepper van hemel en aarde; en God se regering. Die belydenis van God as 'n persoonlike God kom sterk na vore in die ekumeniese belydenisskrifte. Die Apostoliese Geloofsbelydenis begin in die Forma Galicana met die volgende woorde, Ek glo (credo) (Denzinger 1854:2). Sommige tekste soos die Orientalis Hieronsolymitana gebruik die woorde ons glo, wat die persoonlike belydenis beklemtoon (Denzinger 1854:2).

Om die persoonlike verhouding verder te beklemtoon, is dit 'n belydenis van God as Vader. In die geloofsbelydenis van Nicea kom die belydenis van God as Vader vyf keer voor. God as Vader is bý die mens en nie soos die deïstiese gode, verwyderd van die mens nie (Weber 1962:554). Niemand kan na die Vader gaan behalwe deur Christus nie. Die belydenis van Christus se verlossing is daarom van kardinale belang vir die verstaan van die voorsienigheidsleer. Berkouwer (1950:51) ondersteun hierdie stelling en sê 'dat men niet in de werklijke Voorzienigheid Gods kan geloven, als niet verstaan wordt de weg tot de Vader door Christus'.

In die belydenis van Nicea word die eenheid van die drie Persone sterk beklemtoon (Denzinger 1854:11). Om hierdie eenheid verder te beklemtoon, word die beroemde woord, filioque, aan die geloofsbelydenis van Nicea toegevoeg deur Karel die Grote se teoloë in die agtste eeu. Dit word egter eers deur die Pous in 1014 n.C. aanvaar (Praamsma 1979:227). Die belydenis van God as een God en ook die belydenis van die drie-eenheid van God soos in die Belydenis van Athanasius, was veral teen die dwalings van Arius gerig. Vir langer as ' $n$ halwe eeu het die dwalings van Arius die kerk geteister, maar die belydenis van Nicea het die dwaling egter verwerp (Schaff 1931a:44). Arius spreek hom skerp uit teen die belydenis dat Christus die enigste Middelaar is (Schulze 1988:84, 95). Arius stel dat God baie woorde (logosse) spreek en hy vra watter van hierdie woorde is dan nou Christus. Volgens Rushdoony (1978:152) het Arius die moontlikheid van die absolute waarheid vernietig, omdat die waarheid volgens Arius verander en nie verstaanbaar is nie. Vir Arius is God 'n onpersoonlike God. Arius verwys nie na God as Vader nie (Praamsma 1979:88). Van Til (1955:42) skryf dat alle dwalings uit een of ander subordinering in die Drieeenheid ontstaan soos dit in Arius se dwaling aangetoon is. Die belydenis van die Drie-eenheid is dus van die uiterste belang vir die voorsienigheidsleer. Wanneer die verhouding van die drie-enige God tot sy skepping bespreek word, word daar na die ekonomiese Triniteit verwys, skryf Rushdoony (1978:9) in sy boek, The one and the many. Dit sluit die Triniteit se verhouding tot die skepping, onderhouding en regering in. Indien die verhouding van die Triniteit verkeerd verstaan word, kan die verhouding van God tot die skepping, onderhouding en regering daarvan ook nie verstaan word nie.

Die belydenis van God as 'die Skepper van hemel en aarde ${ }^{\prime}, 1$ is eers laat in die ontwikkeling van die Apostolicum ingevoeg (Schaff 1931b:67-75). Die invoeging van hierdie woorde was noodsaaklik in die ontwikkeling van die NiceaKonstantinopelse belydenisskrifte. Die woorde Skepper van hemel en aarde was nie in die teks van die belydenis van die sinode van Nicea (325 n.C.) nie, maar dit is wel teenwoordig in die teks van die sinode van Konstantinopel (381 n.C.). Waarom was dit juis noodsaaklik om hierdie woorde deel te maak van die belydenis? Schulze (1988:28) sê dat die woorde 'Skepper van hemel en aarde' ingevoeg is ter bestryding van die gnostiese dwaling. Die gostiese dwalings het 'n skeiding gemaak tussen die ware God en die Skepper van die wêreld, die demiurg. Hierdie dualisme van die demiurg het veroorsaak dat 'n afkeer van die skepping ontwikkel het (Praamsma 1979:104). Die stryd tussen die Gnostiek en die Christelike geloof was veral baie skerp in die tweede en die derde eeu (Schulze 1988:116). Die stryd teen die Gnostiek het 'n groot invloed in die opstelling van die belydenisskrifte gehad. Die belydenis van God as die Skepper is 'n verwerping van die gnostiese dwaling. God as Skepper is nie boos nie, maar God het die wêreld 'zo lief, dat Hij Zijn eniggeboren Zoon voor die wereld zal overgeven, om haar te behouden' (Praamsma 1979:56).

\section{Die belydenis van God as die almagtige Vader (Denzinger 1854:11)}

Die woord almagtig kom in al drie die ekumeniese belydenisse voor. Die term verteenwoordig twee Griekse woorde, 1.'Creatorem coeli et terrae' (Denzinger 1854:2). 
naamlik 'die absolute gesag of regering' en "n ewige krag'. Alle dinge word gedra of onderhou deur die krag van Jesus Christus, die Seun van God wat aan die regterhand van die Vader sit. ${ }^{2}$ Die 'sit aan die regterhand van die Vader' ${ }^{3}$ dui op die regering van God deur sy Seun. Aan sy koningskap sal daar geen einde wees nie. Die Vroeë Kerk het God as die Regeerder en die Skepper van alle eeue en dinge bely. ${ }^{4}$ Schilder (1951:12) noem 'n belangrike aspek by die regering, naamlik 'regeeren ter bereiking van het voorbedachte einde'. Berkouwer (1950:56) maak ook die onderskeid tussen God se onderhouding wat dien tot die instandhouding en dat die regering 'betrekking heeft op het doel'. Die regering van God is dus tot die doel. Die ekumeniese belydenisskrifte noem die geloof in die ewigheid en die verwagting op die lewe van die toekomstige bedeling as die doel.

In die ekumeniese belydenisskrifte kom die belydenis van God as 'n persoonlike God sterk na vore. Die gelowige kan God slegs Vader noem deur die verlossing van Jesus Christus. Die belydenis van God as die versorgende Vader is die primêre onderskeid met die Hellenistiese filosowe. Die ontkenning van God se Eenheid veroorsaak, soos aangedui is by Arius, dat God 'n onpersoonlike God is. Die beklemtoning van die Drie-eenheid in die ekumeniese belydenisskrifte is daarom belangrik. Die belydenis van God as die almagtige Skepper van hemel en aarde was veral teen die Epikuriërs gerig, wat die Almag van God ontken, asook teen die Gnostiek wat die Skepper-God as die bose God sien. Die belydenis van God as die almagtige Vader, hou verband met die regering van Christus tot die einddoel.

\section{Die voorsienigheidsleer vanuit die Drie Formuliere van Enigheid}

Muller (1991:279) is van mening dat die protestante slegs teen 'n klein gedeelte van die liggaam van die Rooms-Katolieke dogmatiek geappelleer het. Die rede hiervoor is dat die protestante doelbewus teruggryp na die leer van die Vroeë Kerk. Die protestante wou aantoon dat hulle op die leer van die Vroeë Kerk gebou het (Venema 1986:446). Die Drie Formuliere van Enigheid bely ook teen dieselfde dwalings as die Vroeë Kerk. Dit bely byvoorbeeld teen die Manicheërs wat God nie as die skepper van alle dinge bely nie ${ }^{5}$ en teen die Epikuriërs se leer van toeval of geluk, wat beweer dat God geskep het en niks met die aarde te doen het nadat Hy klaar geskep het nie. ${ }^{6}$

In die belydenis oor die voorsienigheid het die reformatore in hulle teruggryp na die Vroeë Kerk veral van die werke van Augustinus gebruik gemaak. ${ }^{7}$ Augustinus se leer oor

2.'Hy, wat die afskynsel is van sy heerlikheid en die afdruksel van sy wese en alle dinge dra deur die woord van sy krag, nadat Hy deur Homself die reiniging van ons sondes bewerk het, het gaan sit aan die regterhand van die Majesteit in die hoogte' (Hebr 1:3; 1953-vertaling).

3.'sedet ad dexteram Dei Patris omnipotentis' (Denzinger 1854:39).

4.... saeculorum omnium et creaturarum regemet conditore' (Schaff 1931b:86).

5.'... itemque et Manichaeorum, qui asserunt, diabolos ex seipsis origenem suam ducere, et ex propria sua natura absque sui corruption malos esse' (Müller 1903:237).

6.'... casui aut fortunae permisisse ...' (Müller 1903:237).

7.'It was Augustine, who created the strict doctrine of predestination in polemic against Pelagius. These problems were brought over into Protestantism in the against Pelagius. These problems were brought over into Protestantism in the
thought of Luther, whose teaching was carried forward by Calvin, Beza, Ursinus, Zanchi, and Piscator' (Muller 1991:6). die voorsienigheid begin by God as die drie-enige God, alomteenwoordige Skepper van alle dinge (elke siel en elke liggaam) ${ }^{8}$ wat klink soos die belydenis van die ekumeniese belydenisskrifte. Gilkey (1976:161) het 'n algemene beginsel by Augustinus se voorsienigheidsleer geïdentifiseer, naamlik die voorsienigheid wat sy oorsprong in God se uitverkiesende wil vind en die kwaad wat tot die doel van God dien. ${ }^{9}$

Reformatore soos Calvyn wat doelbewus teruggegryp het na die Vroeë Kerk, het 'n groot invloed op die belydenisskrifte en veral op die leer van die voorsienigheid gehad. Die gemeente van Keulen het byvoorbeeld versoek dat Genève op die leer van die Nederlandse Geloofsbelydenis moet antwoord. Calvyn het in 'n brief geantwoord op versoek van die gemeente. Hy sê dat Genève niks fout vind met die Nederlandse Geloofsbelydenis nie en dat dit in ooreenstemming is met die Woord van God. ${ }^{10}$ Bierma (2010) toon ook aan dat dit duidelik is dat Calvyn 'n groot invloed op die inhoud van die Heidelbergse Kategismus gehad het.

Die gereformeerde belydenis is van die meer omvattende belydenisskrifte oor die leer van die voorsienigheid (Kuyper 1885:18). Die drie Formuliere van Enigheid is opgestel in 'n tyd van groot vervolging en oorloë. Daarom het dit 'n invloed op die voorsienigheidsleer gehad (George 1984). Die Nederlandse Geloofsbelydenis is byvoorbeeld opgestel in 'n tyd van groot vervolging onder protestantse gemeentes. Guido de Brès het in 1561 die Nederlandse Geloofsbelydenis opgestel en sterf ' $n$ marteldood in 1567 as gevolg van geloofsvervolging (Heyns 1916:20).

Sondag 1 vat die hart van die Heidelbergse Kategismus saam. Dit begin met die volgende vraag: 'Wat is jou enigste troos in lewe en in sterwe?' Hierdie belydenisskrif het in 'n tyd van groot vervolging ontwikkel. Die vervolging het tot gevolg gehad dat die Heidelbergse Kategismus in diaspora gegaan het. As gevolg van die vervolging in Heidelberg het die belydenis so versprei dat dit binne 'n kort tydperk in die meeste lande beskikbaar was, selfs in Amerika (Schaff 1931b:495).

In die opset van hierdie artikel word sommige debatte nagegaan wat' $n$ invloed gehad het op die voorsienigheidsleer van die sestiende eeu, asook op die vier hooftemas in die voorsienigheidsleer vanuit die Drie Formuliere van Enigheid, naamlik die Vader wat deur die Seun Skepper van hemel en aarde is, God as Skepper se onderhouding en regering en die omvattendheid van God se voorsienigheid, asook die probleem van die kwaad.

Die gereformeerde belydenis oor die voorsienigheid van God is dat God die Vader, die skepper van hemel en aarde, deur sy ewige voorsienigheid, oneindige krag, ewige raad, heilige wil

8.... quae tria unum sunt, Deus unus omnia potens, creator et factor omnis animae a atque omnis corporis' (Augustinus 1863 [426 n.C.]:210).

9.'... quoniam qui providenter atque omnipotenter sua cuique distribuit, non solum bonis, cerum etiam malis bene uti nocit' (Augustinus 1863 [426 n.C.]:350).

10.'Iam in forms vestae confessionis nihil animadvertinaus, quos non sit sacris De oraculis et fidei orthodoxae consentaneum. Itaque summam doctrinae quae illio habetur libenter probamus' (Calvin [1575] 1864:224-226). 
en almagtige werking sy skepping, onderhou, bewaar, regeer en bestuur tot ' $n$ doel. Die kern van die voorsienigheidleer in die gereformeerde belydenisskrifte is die belydenis van God as ons Vader en dat hierdie belydenis van God as Vader alleen kan geskied deur die verlossing van Jesus Christus. ${ }^{11}$ Kuyper (1885:69) wys daarop dat wanneer daar na die Skrif en die belydenisskrifte gekyk word, 'dan sien ons, dat, vir sover van die onderskeie persone in die Drie-Eenheid gepraat word die Creatio en Providentia meestal met die werk van die Vader in verband gebring word'. Die belydenis van God as ons Vader, is ' $n$ belydenis van onuitspreeklike troos, ${ }^{12}$ want die Vader wat alles gemaak het, is mý Vader en sonder sy wil, sal daar geen haar van my kop val nie (Müller 1903:682).

Die Vader word ook skepper genoem. As die skepper van hemel en aarde hou dit ook in dat God alles wat Hy geskep het, onderhou en daaroor regeer (Doekes 1979:235). ${ }^{13}$ Die Vader sorg vir 'aardse en gewone brood tot onderhouding van ons aardse lewe'. ${ }^{14}$ Daar is egter ' $n$ noue verband tussen die onderhouding (conservatio) en die bewaring (Erhalt; in Latyn: conserva) in die Drie Formuliere van Enigheid (Müller 1903:717). Die regering (gubernatio) is God se besturing (rego) tot die doel (Müller 1903:237). Die onderhouding en regering van God kan nooit van mekaar geskei word nie (Berkouwer 1950:56).

In die belydenis van God se ewige voorsienigheid leer 'n mens van die omvattendheid van God se voorsiening. God se voorsienigheid gaan meestal saam met voornaamwoorde soos ewige, oneindige, heilige, almagtige en alomteenwoordige. Kuyper (1885:37) skryf dat hierdie voornaamwoorde bygevoeg word om die omvattendheid van God se voorsiening te beklemtoon, byvoorbeeld 'die alomteenwoordige krag is werklik: daar is nie een plek of een oomblik dat God nie teenwoordig is nie'.

Die probleem van die kwaad is 'n algemene tema in die voorsienigheidsleer. In die belydenisskrifte word die probleem van die kwaad omvattend bespreek. Die belydenis maak dit duidelik dat God nie die outeur (autor) van die sonde of die kwaad (pecco) is nie en dat Hy ook nie skuld daarvoor dra nie, ${ }^{15}$ omdat God die mens volkome goed geskape het in 'waaragtige geregtigheid en heiligheid' ${ }^{16}$ Die woorde wat die belydenis gebruik, byvoorbeeld autor, wys dat die protestante doelbewus stry teen diegene wat sê dat hulle God die outeur van die kwaad maak. Die oorsaak van die ongeloof en ook ander sondes lê in die mens en die fout (culpa) lê beslis nie by God nie. ${ }^{17}$

\footnotetext{
11.... umb seines Sons Christi willen, mein Gott und mein Vatter sey ...' (Müller 1903:689).

12. '... ineffabilem consolationem ...' (Müller 1903:237).
}

13.'Duobus autem modis eum cognoscimus: primo, per creationem, conservationem, atque totius mundi gubernationem' (Müller 1903:237).

14.'panem terremum et materialem' in ooreenstemming met die 'ad vitae corporalis et terrenae conservationem' teenoor 'conservationem vitae Spiritualis et coelestis' (Müller 1903:247).

15.'quamvis tamen Deus peccatorum quae fiunt neque autor neque reus sit' (Müller 1903:237).

16.'... warhafftiger gerechtigkeyt und heiligkeyt ...' (Müller 1903:684).

17.'Incredulitatis istius, ut et omnium aliorum peccatorum, causa seu culpa neutiquam est in Deo, sed in homine' (Müller 1903:847).

\section{Beoordeling van König se persoonlike belydenis oor God se voorsienigheid}

Van Wyk (2002:539) wys daarop dat dit nie maklik is om met König oor die voorsienigheidsleer in gesprek te tree nie, omdat sy voorsienigheidsleer oorspronklik, weldeurdag, helder geformuleer, logies opgebou en die vrug van deeglike besinning en baie gebed is. König vergelyk baie Skrifgedeeltes met mekaar en raadpleeg ook verskeie teoloë se verklaring daarvan. Dit is verder duidelik dat König wil vashou aan die gesag van die Bybel.

In die beoordeling van König se voorsienigheidsleer word na drie grondtrekke van König se voorsienigheidsleer gekyk, naamlik die eskatologiese verbondsleer, die kwessies van die kwaad en die mag van God.

\section{Eskatologiese verbondsleer}

Die eskatologiese verbondsleer is die kern van König se teologie. König (2000:24) het van die begin af in die eskatologie belang gestel en onder die invloed van Barth se Christosentriese teologie het hy reeds in sy proefskrif tot die volgende gevolgtrekking gekom: 'Eskatologie is teleologiese Christologie, naamlik Jesus Christus die eschatos wat die doel van God met sy skepping bereik ... vir ons, in ons en met ons.' (König 1970:243.) Vir König is die hooftema van die Bybel die eskatologiese verbondsleer en die 'wese van God' word daarin gevind dat Hy 'n 'Verbondsgod' is (Strauss 2004:134). König se hele dogmatiek moet dus verstaan word binne sy eskatologiese verbondsleer. Strauss (2004:138) vra egter of König se oorbeklemtoning van die eskatologiese verbondsleer nie 'n aanduiding van 'n 'ongebalanseerde eskatologiese oorywerigheid is nie' en of König se oordrewe eensydige beklemtoning van die eskatologie nie daartoe lei dat hy God se beheer slegs tot die toekoms beperk nie.

In König (2001:321) se eskatologiese verbondsleer werk hy nie met die ordelike ontplooiing of skeppingsordeninge nie, maar eerder met die ingryping van God binne die chaos. Die rede waarom König met die ingryping, of soos hy (König 2002:172-174) dit noem, 'die wendings wat God in die geskiedenis maak', werk, is omdat God volgens König nie in beheer is nie. God moet dus ingryp om die rigting van die geskiedenis te verander, sodat Hy sy einddoel met die wêreld kan bereik.

\section{Die kwessie van die kwaad}

König bring ' $n$ unieke indeling in die voorsienigheidsleer, deurdat hy sy leer begin met die kwaad. Hy doen dit omdat hy 'n sinvolle voorsienigheidsleer wil uitwerk wat aktueel is en nie ' $n$ wêreldvreemde, idealistiese leer is wat pragtig klink, maar nie die werklike uitdagings van die geloofsleer kan hanteer nie (König 2002:73).

Om König se denkontwikkeling rondom die probleem van die kwaad te verstaan, moet sy denkontwikkeling rondom 
sy verstaan van die erfsonde nagegaan word. König se verwerping van die erfsonde soos Augustinus dit geleer het, is iets wat hy eers laat in sy lewe ontwikkel het. Dit word duidelik wanneer hy in die 2001-uitgawe van Fokus op die 300 geloofsvrae sê dat 'ons die erfsonde aanvaar sonder dat ons dit mooi verstaan' (König 2001b:240). 'n Jaar later, in 2002, verwerp hy egter die erfsonde in sy boek God, waarom lyk die wêreld so? Hierin sê hy: 'Dit kos byvoorbeeld 'n baie harde erfsondeleer om te aanvaar dat daardie mense (wat sinlose lyding ervaar) se vreeslike lyding die regverdige en verdiende straf van God was' (König 2002:151). In 2004 word dit nog duideliker in 'n artikel in Beeld, 'Erf ons sonde of erf ons genade?' waarin König die leer van die erfsonde nie nodig ag vir die kerk nie (König 2004:8). Hierdie ontwikkeling in König se denke wat begin by die aanvaarding van die leer oor die erfsonde tot die verwerping van die leer, het moontlik 'n aantal redes. Een rede wat duidelik uitstaan, is dat König se leer aangaande die kwaad 'n invloed op sy verstaan van die erfsonde gehad het.

Erfsonde (peccatum originale) is 'n leer wat deur Augustinus vanuit die Woord uitgewerk is in sy stryd teen Pelagius (Heyns 1978:190). Dit is die leer dat niemand uitgesluit is van die sonde nie en dat almal van hulle geboorte af aan die sonde deel het. Die term erfsonde poog om die reikwydte van die sonde aan te dui en ook om die gemeenskaplike sondigheid van alle mense wat met Adam en Eva begin het, aan te dui. Die vertrekpunt wat die leer van die erfsonde neem, is dat die mens ' $n$ sondaar is en daardeur geneig is tot alle kwaad. Die mens en sy bose dade is daarom nie 'n skok nie, maar 'n gegewe (Heyns 1978:190).

Deurdat König die erfsonde ontken, word sy onvermoë verhoog om te verstaan hoe God die sonde kan straf of die kwaad kan beskik. In König se verwerping van die erfsonde, ontken hy dat die mens gebore is as 'n sondaar en die dood verdien. Vanuit hierdie uitgangspunt vra König egter die verkeerde vrae, byvoorbeeld: God, waarom lyk die wêreld so?, Hoe kan 'n goeie God sulke slegte dinge laat gebeur?, Hoe kan God toelaat dat 'n arme babatjie vermoor word?, ensovoorts. König gaan soek daarom antwoorde op vrae wat vanuit 'n humanistiese grondslag gevra word en nie vanuit die beginsel dat die mens wel die dood verdien omdat hy in sonde ontvang en gebore is nie. ${ }^{18}$

\section{God die Magtige}

Die hoofdoel van God se mag is volgens König (2002:225) om sy liefde te toon. Die hoofuitspraak in die Skrif is dat God liefde is en hierdie uitspraak kom talle male in die $\mathrm{Ou}$ Testament voor. Dit lui dat God barmhartig en genadig is, lankmoedig, vol liefde en trou (König 2002:225). Mag moet volgens König (2002:219) ook nie verstaan word as God wat kan doen wat Hy wil nie, maar eerder as God wat wel sy doel in die einde sal bereik. König (2002:226) verstaan almag as die liefdevolle mag van Christus om te kies om Homself aan 'n skandelike kruisdood prys te gee.

18.'Kyk, in ongeregtigheid is ek gebore, en in sonde het my moeder my ontvang; (Ps 51:5)
König (2002:14) ontken nie die almag van God nie, maar die mens moet volgens hom almag verstaan soos die Bybel leer, omdat die Bybel nie die woorde 'God die Almagtige' gebruik nie. Hierdie stelling van König is egter nie korrek nie. In Genesis 17:1 sê die Here: 'Ek is God die Almagtige, wandel voor my aangesig. ${ }^{19}$ Die Hebreeuse woord vir Almagtige (shaddai) word in die LXX vertaal as die Almagtige (pantokrator) en in die Vulgaat as die Almagtige (omnipotens). In die Nuwe Testament kom die woord die Almagtige (pantokrator) nege keer in Openbaring voor. ${ }^{20}$ Die Bybel praat in geen onduidelike terme van God se almag nie (Berkhof 1976:80).

König (2002:219) noem tereg dat die almag van God nie verstaan moet word as 'n mag wat God het, sodat Hy enige oomblik enigiets kan doen wat Hy wil nie. God kan nie dinge doen wat met sy Wese in stryd is nie. God se almag is dus nie in staat om Homself nie meer God te laat wees nie. Die almag van God is die mag van sy Wil en sy Wil is die wil wat met sy Wese in volledige harmonie is. God kan byvoorbeeld nie lieg nie, nie Homself verloën nie en ook niemand in die versoeking lei nie.

Hierdie almag van God word deur die Vroeë Kerk aan die belydenis van die Vader verbind. Die woord almagtig kom in al drie die ekumeniese belydenisse voor. Volgens König (2002:226) moes die woord almagtige nie by die Vader geplaas word nie, maar by die werk van die Seun, want König meen dat die woorde 'God die almagtige Vader' slegs op harde mag van God dui en nie op God se sagte mag nie.

König loop die gevaar om God se almag te beperk tot slegs die krag van verlossing. Van Genderen en Velema (1992:181) maak dit duidelik dat God se almag juis altyd gesien moet word vanuit die Vaderlike, omdat die belydenis van God die almagtige Vader beklemtoon dat die almag nie op God dui wat doen net wat Hy wil nie, maar dat Hy as persoonlike Vader doen wat in ooreenstemming is met sy Wil. Daar kan daarom nie na God se Almag verwys word as daar nie ook na sy Wil verwys word nie. Die feit dat God sekere dinge nie kan doen nie, is nie onmag nie, maar eerder God wat dit nie wil doen nie.

König (2002:145) onderskei tussen beheer in die absolute $\sin$, beheer in die enger sin en beheer in die ruimer sin. Hy verwerp die beheer in die absolute sin wat volgens hom by Calvyn voorkom, asook Ridderbos (1972:97) se verklaring van Jesaja 45:7, omdat God volgens König nie die bewerker van alle dinge is nie. König verwerp ook beheer in die enger sin, omdat God volgens hom nie gebeure kan toelaat soos Auschwitz en net toekyk sonder om iets te doen nie. König verstaan die woorde 'God is in beheer' in die ruimer sin. Wat hy hiermee bedoel, is dat God in beheer is van dinge op aarde sover dit nie hand uitruk nie. Die geskiedenis is daarom vir König oop in die sin dat God nie alles bepaal wat gebeur nie.

19.'Toe Abram nege en negentig jaar oud was, het die HERE aan Abram verskyn en vir hom gesê: Ek is God, die Almagtige; wandel voor my aangesig, dan sal jy opreg wees' (Gen 17:1).

20.'En ' $n$ tempel het ek nie daarin gesien nie, want die Here God, die Almagtige, is sy tempel, en die Lam' (Op 21:22). 
König sê dat ons nie altyd iemand moet soek wat in beheer is nie. Dus is daar volgens hom nie een persoon, God of die Duiwel, wat in absolute beheer is nie (König 2002:175). Al waar God volgens König nog in beheer is, is die feit dat Hy sy doel sal bereik. Verder het König die beheer van God in sy totaliteit opgegee, omdat ons volgens König nie kan sê dat God enigiets bepaal nie. Hoewel König die woorde 'God die Almagtige' of 'God is in beheer' wil behou, het hy dit in die uitwerking van sy voorsienigheidsleer prysgegee.

Volgens Swinburne (2003:56) besit God eienskappe soos ewig, onbegryplik, onsienlik, onveranderlik, oneindig, almagtig, wys, regverdig, goed en heilig. Verder sê hy dat die teïsme nie net beweer dat God hierdie eienskappe het nie, maar meer nog, dat hierdie eienskappe noodsaaklik is. As God nie hierdie eienskappe het nie, is God nie God nie. Die gevaar wat König dus loop in sy voorsienigheidsleer is dat hy God se voorsienigheid ontken, omdat hy God tot 'n magtelose god verlaag wat nie kan voorsien nie, dus 'n ander god.

Volgens König sal daar nie die vreeslike dinge met God se kinders gebeur indien $\mathrm{Hy}$ in beheer was nie. König (2010:25) verwys na die gebeurtenis in Desember 2010 waar die Potgieter-gesin van Lindley op hulle plaas koelbloedig vermoor is. Volgens König kan 'n mens nie sê dat God hierdie gebeure beskik het nie, maar dat Hy sy kinders in moeilike omstandighede help en saam met hulle huil in tye van swaarkry. Die troos waaraan God se kinders moet vashou, is dat God wel sy doel sal bereik (König 2010:25).

Niemand is in beheer nie, selfs nie God nie! Hierdie uitspraak laat talle mense se hare rys. Dit is ook 'n groot rede waarom König se boek, God, waarom lyk die wêreld so?, soveel aftrek gekry het. Hierdie radikale uitspraak dat niemand in beheer is nie, sal natuurlik baie reaksie ontlok, want dit is ' $n$ uitspraak wat teen die leer van die kerk van al die eeue indruis. Hierdie leer dat God nie in beheer is nie, kan onsekerheid by baie mense bring. König (2002:175) sê self ook dat dit onsekerheid by mense kan bring, maar dat die Bybel se geskiedenis vol van onsekerhede is.

Die uitspraak dat niemand in beheer is nie, saai onsekerheid by mense en kan mense laat twyfel of hulle nog moet bid. Indien God nie in beheer is nie, hoekom moet daar nog tot Hom gebid word? Dit word veral duidelik in 'n berig van Beeld waar 'n predikant sê dat 'n mens nie kan bid dat God jou veilig moet hou in jou motor en jou op die pad moet bewaar nie. Volgens die predikant werk gebed nie so nie (Jackson 2011:24). Hy sê hy ken drie gesinne wat gebid het dat die Here hulle kinders op die pad moet bewaar en elkeen van die gesinne het twee kinders in padongelukke verloor. Net so maak dit nie vir hom sin om vir reën te bid nie. Hy glo nie dat God die weerstelsels beheer nie. Daar is groot natuurkragte wat dit beheer, nie God nie. Gebed gaan vir daardie predikant ten diepste oor die manier wat die mens God verstaan (Jackson 2011:24). König sal sy verstaan van God se beheer ook ten opsigte van gebed moet verantwoord, want waarom moet mense dan bid as God niks aan die saak kan doen nie?
In onsekerheid moet God se kinders juis vashou aan die troos dat God in beheer is, sodat hulle nie in onsekerheid hoef te leef nie. Die geloofsbelydenis is nie iets wat onseker is nie, maar geloof is juis 'n vaste vertroue. God se kinders moet daarom altyd vashou aan die woorde van die geloofsbelydenis in die Heidelbergse Kategismus, Sondag 1:

Wat is jou enigste troos in lewe en in sterwe? Dat ek ... aan Jesus Christus behoort ... Hy bewaar my op so 'n wyse dat, sonder die wil van my Hemelse Vader, geen haar van my kop kan val nie,.$^{21}$

God se kinders moet altyd vashou aan hierdie troos dat God in beheer is en dat daar niks met hulle sal gebeur wat buite sy Wil is nie.

König dui God se magteloosheid aan wanneer hy sê dat God se mag beperk is. Dit is vir König uit die totale geskiedenisbeeld van die Ou Testament duidelik, aangesien Satan die volk Israel in ballingskap van God weglei (König 2002:170-172). Hierdie bewering van König is egter nie vanuit die Skrif deurgrond nie. Dit word duidelik uit Jeremia 27 en 28 dat God koning Nebukadnesar sterk gemaak het en aan hom al die lande gegee het. Die Here het ook Israel aan Nebukadnesar oorgegee. Die Here het dus die ballingskap bewerk en nie Satan nie (Aalders 1954:38). ${ }^{22}$

Volgens König (2002:234-235) kry God ook nie altyd alles reg nie. Hy verwys byvoorbeeld na Jona en sy ongehoorsaamheid. God het volgens König dit nie reggekry dat Jona die eerste keer na Hom luister nie, maar wel die tweede keer. Hierdie uitspraak van König hou ook geen water nie. Wanneer na die res van die Skrif gekyk word, word dit duidelik dat Jona as teken van Christus dien. Soos wat Jona drie dae en drie nagte in die maag van 'n groot vis was, so was Jesus Christus ook drie dae en drie nagte in die hart van die aarde..$^{23}$ Jona se ongehoorsaamheid is nie 'n teken dat God nie altyd alles regkry nie, maar dit dui juis God se almag en alwetendheid aan, omdat Jona se optrede op Christus se kruisiging en oorwinning van die kwaad dui (Grosheide 1954:205).

'n Verdere aanduiding, volgens König, waarom God nie altyd alles regkry nie, is die gedeeltes wat daaroor gaan dat God berou getoon het. Hierdie tekste wat aandui dat God berou betoon, byvoorbeeld Genesis 6:6, Eksodus 32:14, 1 Samuel 15:11 en Jona 3:10, bestaan en kan nie vermy word nie. Wat König egter nie in ag neem nie, is dat daar ook tekste is wat sê dat God nie berou toon nie, byvoorbeeld 1 Samuel 15:29, Numerie 23:19, Psalm 110:4 en Romeine 11:29.

Heyns (1978:64) verklaar hierdie gedeeltes nie as botsende uitsprake nie en sê 'ons kan dit seker vir geen oomblik aanvaar nie'. Volgens Heyns moet berou nie verklaar word

21.'Was ist dein einiger Trost in Leben und in Sterben? Das ich ... Jesu Christi eigen bin, ... und also bewaret, das ohne dem Willen meines Vatters im Himmel, kein Haar von meinem Haupt kan fallen, ...' (Müller 1903:682).

22.'En nou het Ék al hierdie lande gegee in die hand van Nebukadnésar, die koning van Babel, my dienaar; ja, selfs die wilde diere van die veld het Ek aan hom gegee om hom te dien' (Jer 27:6).

23.'Want soos Jona drie dae en drie nagte in die buik van die groot vis was, só sal die Seun van die mens drie dae en drie nagte in die hart van die aarde wees' (Matt 12:40). 
as onwetendheid van God of 'n foutiewe handelswyse van God wat herroep moet word nie. Die berou van God moet eerder verstaan word as 'n smartkreet van God - God wat ween oor die ongehoorsaamheid van sy volk en vanweë sy geregtigheid dit ook moet straf.

Volgens König ly God ook nederlae. Die kruisiging is een voorbeeld wat König (2002:173) noem as aanduiding vir die nederlae wat God ly, omdat die kruisiging volgens König 'n mislukte poging was om Israel te probeer verlos. Hierdie uitspraak van König is ook nie deurgrond nie en dit is duidelik in stryd met die Skrif, byvoorbeeld in Handelinge 2:23 en 4:27-28 wat aandui dat God deur sy bepaalde raad en voorkennis Jesus aan die goddelose manne oorgegee het om gekruisig te word. ${ }^{24}$ Die kruisiging was nie'n mislukte poging om ons te verlos nie, maar dit was die vooruitbepaalde keuse van God dat Jesus Christus gekruisig sou word (Grosheide 1962:35).

Hoewel God volgens König (2002:219) nie in beheer van alle dinge is nie, sal Hy wel sy doel bereik. Van Wyk (2002:545) vra egter tereg vir König: 'As God nie nou in volle beheer is nie, kan iemand dan nie regmatig daaraan begin twyfel of Hy wel sy eskatologiese doel sal bereik nie?' Indien God eenmaal beheer verloor het, kan God nie weer eendag beheer verloor nie, of sal God weer sy beheer terugkry? König kan nie verseker weet dat God eendag sal regeer nie en indien hy dit verseker kan weet, verval König volgens sy eie standaarde ook in determinisme. König se ontkenning van God se beheer saai onsekerheid en veroorsaak twyfel by gelowiges.

\section{König se posisie teenoor die gereformeerde belydenisskrifte}

König (2001:222) haal die belydenisse op talle plekke aan, byvoorbeeld Nicea en Chalcedon in verband met die Christologie, die Nederlandse Geloofsbelydenis in verband met die nagmaal (König 2001:323), die gereformeerde doopsformulier in verband met die doop (König 2001:311), of die Heidelbergse Kategismus wanneer hy na die heerskappy van Christus verwys (König 2001:321). Dit is egter opvallend dat König glad nie sy voorsienigheidsleer in verband bring met die gereformeerde konfessie nie. Volgens Van Wyk (2002:550) is dit jammer dat König nie in gesprek tree met die gereformeerde konfessie nie, want dit sou bydra tot die aktualiteit van sy studie.

König verwys die meeste kere krities en in 'n negatiewe sin na die belydenisskrifte, byvoorbeeld na die Apostoliese Geloofsbelydenis wat net na die Almag van God verwys (König 2001:57). In sy behandeling van die voorsienigheidsleer is König sonder twyfel in stryd met die gereformeerde belydenisskrifte, byvoorbeeld Sondag 10 van die Heidelbergse Kategismus en Artikel 13 van die Nederlandse Geloofsbelydenis. In König se persoonlike

24.'Hom, wat deur die bepaalde raad en voorkennis van God oorgelewer is, het julle deur die hande van goddelose manne geneem en gekruisig en omgebring.' (Hand 2:23); en Hand 4:27-28 'Want waarlik, Herodes en Pontius Pilatus het saam met heidene en die volke van Israel vergader teen $u$ heilige Kind Jesus wat $U$ gesalf het, om alles te doen wat $u$ hand en $u$ raad vooruit bepaal het om plaas te vind' het, om alles te geloofsbelydenis sê hy dat God nie alle rampe kan keer nie en nie alle probleme kan oplos nie (König 2002:236). Hierteenoor bely die Heidelbergse Kategismus, Sondag 10 dat alles wat ons toekom uit die Vader se hand is en in die Nederlandse Geloofsbelydenis, artikel 13 dat niks sonder die beskikking van God sal gebeur nie.

Hieruit kan afgelei word dat König se teologie 'gekenmerk word deur 'n gebrek aan konfessionele binding' - veral in sy leer oor die voorsienigheid (Strauss 2004:131). König (2003:738) erken ook dat hy in die woorde 'God ly soms neerlae' onkonfessionele taal gebruik. Dit is dus duidelik dat dit nie vir König kommerwekkend is dat hy in stryd is met die gereformeerde konfessie nie. König het volgens Van Wyk (2002:529) 'n nuut-ontwerpte voorsienigheidsleer, omdat hy onkonfessioneel te werk gaan. Van Wyk (2002:550) se gevolgtrekking is dat König se voorsienigheidsleer so ver van die gereformeerde belydenis wegbeweeg dat hy 'n kerklike oordeel oor sy standpunt sal moet aanvra.

Net soos König, stel Potgieter (1996) ook die vrae wat deur die voorsienigheidsleer na vore gebring word aan die orde:

Is it not a caricature of divine providence to state that really everything happens according to God's will? Does this not create insurmountable problems for the faithful when they themselves are confronted by every kind of disaster? (bl. 197)

Anders as König egter, verlaat Potgieter nie die pad van die Skrif en gereformeerde konfessies nie (Potgieter 1996:204207). Om die leer van die voorsienigheid werklik te verstaan, moet die kerk en die teologie vashou aan die sola Scriptura(die Skrif alleen-) beginsel. Hierdie standpunt vind ook steun by 'n teoloog soos John Webster. 'The task of a Christian theology of providence can be undertaken only by drawing upon the resources given to it by the gospel ... otherwise it has nothing to say' (Webster 2009:159). ${ }^{25}$ Potgieter (1996:198, 199; vgl. ook Potgieter 2006) verwys ook met instemming na die standpunt van Calvyn en deel nie König se kritiek op Calvyn nie. Leidende gereformeerde dogmatici (vgl. onder andere Van den Brink \& Van der Kooi 2012:222) vind ook in die problematiek van die teenswoordige tyd steeds aansluiting by Calvyn se beklemtoning dat ons die verborge oordele van God moet eerbiedig.

\section{Gevolgtrekking}

König is 'n aktuele en invloedryke teoloog en sy standpunte kan nie geïgnoreer word nie (Strauss 2004:123). König (2002:13) beskou homself as 'n gereformeerde teoloog. Tog verskil sy voorsienigheidsleer van die klassieke gereformeerde siening. In sommige gevalle word König se teologie as reformatories gesien (bv. sy leer oor die regverdigmaking) en in ander gevalle weer nie soos met die leer oor die voorsienigheid (Strauss 2004:139).

Die klassieke gereformeerde verstaan van voorsienigheid is volgens König (2002:33) nie vertroostend nie. Die klassieke

25. Die klem val in hierdie artikel op ' $n$ beoordeling van König se voorsienigheidsleer in die lig van die gereformeerde belydenisskrifte. Die outeurs het egter wel kennis geneem van resente publikasies soos onder andere dié van Van den Brink en Van geneem van resente publikasies soos onder andere die van Van den Brink en Van
der Kooi (2012) en Murphy en Ziegler (2009). In 'n artikel met ' $n$ ander fokuspunt, sou meer breedvoerig aan hierdie en ander publikasies aandag gegee moes word. 
gereformeerde siening van die voorsienigheid maak ook, volgens König, van God 'n bose God wat die kwaad beskik en dan net toekyk as die kwaad gebeur. König (2002:237) se oplossing vir die probleem van die klassieke gereformeerde siening is dat God nie ten volle in beheer is nie, maar dat Hy eers eendag in beheer sal kom. Hierdie siening van König is in stryd met die gereformeerde belydenis waarin bely word dat God deur sy voorsienige hand alle dinge onderhou en regeer.

Die voorsienigheidsleer vanuit die gereformeerde belydenisskrifte kan onderskei word van Adrio König se voorsienigheidsleer, indien gelet word op die twee begrippe professio en confessio. Dit is merkwaardig dat die reformatore gedurende die Reformasie die begrip confessio vir belydenis van die geloof gebruik het. Die reformatore het doelbewus téén die kontemporêre Rooms-Katolieke ekwivalent, professio, gekies (Britz 1999:5).

Volgens Van Wyk (2002:545) het König eers 'n bepaalde Godsbeeld ontwikkel en daarna die Skrifgegewens bygewerk. Dit is presies wat met professio bedoel word. Professio is ' $n$ amptelike verklaring of verwoording van 'n saak wat self tot stand gebring is en dit ontwikkel nie uit die openbaring nie. Professio gee rekenskap van die eie insig en herinterpretasie of die aktualiserings van die tradisie. Professio staan altyd in verband met die aflê van 'n menslike geloofsgetuienis. 'n Gemeente wat die belydenisskrif as confessio verlaat het, kry plaasvervangers daarvoor soos die vernuwing van die geloof, 'n herlewing, of die kontekstualisering daarvan (Britz 1999:6). König se oproep tot 'n aktuele voorsienigheidsleer, los van die openbaring van God, is daarom 'n logiese gevolg uit sy persoonlike menslike geloofsgetuienis (professio).

Teenoor 'n persoonlike menslike geloofsgetuienis (professio) staan 'n geloofsbelydenis (confessio), wat 'n erkenning en vereenselwiging met ' $n$ saak is en wat nie deur menslike toedoen ontstaan het nie. Die ontstaan van die saak word dan bely, confessus. Deurdat die reformatore vír die begrip confessio gekies het, het hulle werklik die wesenlike aard van die geloof na vore gebring. Confessio beklemtoon dat geloof ' $n$ middel is wat deur God geskenk is. Die geloof en die belydenis van daardie geloof (confessio) kom in diens van die oortuiging dat ' $n$ mens uit genade alleen gered word. Petrus se belydenis dat Jesus die Seun van die lewende God is, het van die Vader gekom. Die confessio van Petrus het dus sy oorsprong uit die openbaring van die Vader. 'n Geloofsbelydenis (confessio) is dus in ooreenstemming met die openbaring van die Skrif en verklaar daarom nie die rekenskap van 'n teologiese of kerklike verklaring nie (Britz 1999:6-7).

Indien König (2002:175) se persoonlike geloofsbelydenis vergelyk word met dié van die gereformeerde belydenisskrifte, is dit duidelik dat ' $n$ verklaring van ' $n$ mens se troos nie vergelyk kan word met die troos van die Woord nie. König se verklaring dat God by jou is in tye van nood, maar nie in beheer is nie, is juis nie troosvol nie, maar bring eerder meer verwarring en wanhoop, sodanig dat mense kan begin twyfel om te bid. Waarom moet mense bid indien God niks aan die saak kan doen nie? (Jackson 2011:24).

Gebeure soos die 2001-aanvalle op die Wêreld-Handelsentrum in New York het die vraag na God se voorsienigheid weer oopgekrap. Dit is moelik om antwoorde op die volgende hartsvrae te kry: Waar is God in hierdie swaarkry, deurmekaar wêreld? Waar was God tydens die tsunami's in Japan? Waar was God tydens die 2001-terreuraanvalle op New York? Waar was God tydens die moorde op die Jode in die Tweede Wêreldoorlog? Hierdie vrae is lewensvrae waarmee baie mense worstel. 'n Mens kan maar net kyk na al die boeke wat die laaste paar jaar oor die onderwerp gepubliseer is. Die noodsaaklikheid dat ons juis in 'n tyd soos vandag waar mense so baie vrae het as gevolg van die lyding en kwaad, vrae oor die voorsienigheid maar ook oor God self vra, beklemtoon die dringendheid na vastigheid - die vastigheid van God se Woord. Niks anders kan werklik troos bring nie. Die gereformeerde belydenisskrifte, byvoorbeeld die Heidelbergse Kategismus wat ontwikkel is in 'n tyd van groot vervolging, bied egter 'n groot troos, die troos van die Woord self. Dit is die troos dat ons in lewe en in sterwe aan Jesus Christus behoort.

\section{Erkenning Mededingende belange}

Die outeurs verklaar dat hulle geen finansiële of persoonlike verbintenis het met enige party wat hulle nadelig kon beïnvloed het in die skryf van hierdie artikel nie.

\section{Outeursbydrae}

Beide outeurs, M.D. (Noordwes-Universiteit) en C.F.C.C. (Noordwes-Universiteit) het gelyke bydraes gelewer tot die navorsing en skryf van hierdie artikel.

\section{Literatuurverwysings}

Aalders, C.H., 1954, De profeet Jeremia: Korte verklaring der Heilige Schrift, Kok, Kampen.

Augustinus, A., [426 n.C.] 1863, De Civitate Dei, Vol. 1, B. Dombart (ed.), Teubneri, Lipsiae.

Berkhof, L., 1976, Systematic theology, Cox \& Wyman, London.

Berkouwer, G.C., 1950, De voorzienigheid Gods: Dogmatische studiën, Kok, Kampen.

Bierma, L.D., 2010, 'Calvin's influence on the Heidelberg Catechism: The doctrine of providence', Paper at the International Calvin Congress, Bloemfontein, 22-27 August.

Britz, R.M., 1999, 'Goeie wyn het nie 'n uithangbord nodig nie: Die onmisbaarheid van die gereformeerde belydenisskrifte vir die gemeente vandag', UV Teologiese Studies 1(10), 5-13.

Calvin, J., [1575] 1864, 'Consilium: Ad quaestiones cirva diciplinam ecclesias response', Vol. 10, in C. Baum (ed.), loannis Calvini opera quae supersunt omnia, ad corpus Reformation, Schwetschke, Braunschweig.

Denzinger, H., 1854, Enchiridion symbolorum definitionum, quae in rebus fidei et morum a Conciliis oecumenicis et summis Pontificibus, Sumptibus Stahelianis, Wirceburgi.

Doekes, L., 1979, Credo: Handboek voor de gereformeerde symboliek, Ton Bolland, Amsterdam.

George, T., 1984, 'War and peace in the puritan tradition', Church History: Studies in Christianity and Culture 53(4), 492-503. http://dx.doi.org/10.2307/3166119

Gilkey, L.B., 1976, Reaping the whir/wind: A Christian interpretation of history, Seabury Press, New York.

Grosheide, F.W., 1954, Het heilige evangelie volgens Mattheus, Kok, Kampen. (Commentaar op het Nieuwe Testament). 
Grosheide, F.W., 1962. Handelingen: Korte verklaring der Heilige Schrift, Kok, Kampen. Heyns, J.A., 1978, Dogmatiek, N.G. Kerkboekhandel, Pretoria. PMCid:PMC1145538 Heyns, W., 1916, Gereformeerde geloofsleer, Eerdmans, Michigan.

Jackson, N., 2011, 'Bid werk nie, sê dominee', Beeld, 28 Febuary, p. 24.

König, A., 1970, Jesus Christus die Eschatos: Die fundering en struktuur van die eskatologie as teleologiese Christologie, NG Kerk-Boekhandel, Pretoria. PMCid:PMC1820397

König, A., 2000, 'How my mind is changing, but ...' Unpublished paper delivered at the Annual Congress of the Theological Society of Southern Africa, June.

König, A., 2001, Fokus op die 300 geloofsvrae wat mense die meeste vra: 'n Verwysingsgids vir elke huis, Lux Verbi, Wellington.

König, A., 2002, "God, waarom lyk die wêreld só?" Kan ons sê: "God is in beheer ?", Lux Verbi.BM., Wellington.

König, A., 2003, 'Van Wyk se bespreking van my boek: "God, waarom lyk die wêreld so?"', In die Skriflig 37(4), 735-740. http://dx.doi.org/10.4102/ids.v37i4.491

König, A., 2004, 'Erf ons sonde of erf ons genade?', Beeld, 9 Augustus, p. 8.

König, A., 2010, 'Jesus huil, want sy Vader gee om, ek lees nie dat God alles beskik nie', Beeld, 14 Desember, p. 25.

Kuyper, A., 1885, 'Locus de Providentia', in A. Kuyper, Locus de Providentia, Peccato, Foedere, Christo: Dictaten Dogmatiek van Dr. A. Kuyper, Band 3, Kok, Kampen.

Müller, E.F.K., 1903, Die Bekenntnisschriften der reformierten Kirche, Lippert, Leipzig.

Muller, R.A., 1991, God, creation, and providence in the thought of Jacob Arminius, Baker Book House, Michigan.

Murphy, F.A. \& Ziegler, P.G. (eds.), 2009, The providence of God: Deus habet consilium, Clark, London.

Naude, P., 2002, 'Kan ons nog sê God is in beheer?', Beeld, 5 Augustus, p. 7.

Potgieter, P.C., 1996, 'The doctrine of divine providence: A dilemma for reformed theology?', in A. van Egmond \& D. van Keulen (eds.), Freedom, Papers from a conference held by the International Reformed Theological Institute, pp. 195207, Callenbach, Baarn.

Potgieter, P.C., 2006, 'Providence in Calvin: Calvin's view of God's use of means (media) in his acts of providence', in D.F. Wright, A.N.S. Lane \& J. Balserak (eds.), Calvinus evangelii propugnator Papers of the International Congress on Calvin Research, Seoul, 1998, pp. 175-190, published for the Calvin Studies Society.
Praamsma, L., 1979, De kerk van alle tijden, Deel 1, Wever, Franeker. Ridderbos, J., 1972, De profeet Jesaja, Deel 2, Kok, Kampen.

Rushdoony, R.J., 1978, The one and the many, Thoburn Press, Virginia. PMid:12178554

Schaff, P., 1931a, The creeds of Christendom, with a history and critical notes, Vol. 1 , 6th edn., Christian Classics Ethereal Library (CCEL), New York.

Schaff, P., 1931b, The creeds of Christendom, with a history and critical notes, Vol. 2, 6th edn., Christian Classics Ethereal Library (CCEL), New York.

Schilder, K., 1951, Heidelbergsche Catechismus, Zondag 10, Oosterbaan \& Le Cointre, Goes.

Schulze, L.F., 1988, Geloof deur die eeue, N.G. Kerkboekhandel, Pretoria.

Strauss, S.A., 2004, 'Grondtrekke van Adrio König se teologie', Acta Theologica Supplementum 6, 122-141.

Swinburne, R., 2003, 'God', in C. Taliaferro \& P.J. Griffiths (eds.), Philosophy of religion: An anthology, Blackwell, Malden.

Van den Brink, G. \& Van der Kooi, C., 2012, Christelijke dogmatiek, Boekencentrum, Zoetermeer.

Van Genderen, J. \& Velema, W.H., 1992, Beknopte gereformeerde dogmatiek, Kok, Kampen.

Van Til, C., 1955, The defense of the faith, Presbyterian \& Reformed Publishing, Philadelphia.

Van Wyk, J.H., 2002, 'Die mens wik maar God beskik? In gesprek met Adrio König oor sy eskatologiese, verbondsmatige voorsienigheidsleer', In die Skriflig 36(4), 529-553. http://dx.doi.org/10.4102/ids.v36i4.524

Venema, C.P., 1986, 'Heinrich Bullinger's correspondence on Calvin's doctrine of predestination, 1551-1553,' The Sixteenth Century Journal 17(4), 435-450. $\mathrm{http}: / / d x$.doi.org/10.2307/2541382

Weber, O., 1962, Grundlagen der Dogmatik, Bd. 2, Neukirchener Verlag, Neukirchen.

Webster, J., 2009, 'On the theology of providence', in F.A. Murphy \& P.G. Ziegler (eds.), 2009, The providence of God: Deus habet consilium, pp. 158-175, London, Clark. 